\title{
Temporal Variability of Suspended-Solids Concentration in the Estuarine Channel of Patos Lagoon, Southern Brazil
}

\author{
Rafael André Ávila ${ }^{1, *(1)}$, Priscila Mulattieri Suarez Orozco ${ }^{1,+}$, Mauro Michelena Andrade 2 (1) \\ and Osmar Olinto Möller, Jr. ${ }^{1}$ \\ 1 Laboratório de Oceanografia Costeira e Estuarina, Instituto de Oceanografia, Universidade Federal do Rio \\ Grande, Avenida Itália km 8, Rio Grande, RS 96203-900, Brazil; priorozco@gmail.com or \\ priscila.orozco@ul.com (P.M.S.O.); dfsomj@furg.br (O.O.M.J.) \\ 2 Laboratório de Oceanografia Física, Programa de Pós-Graduação em Ciência e Tecnologia Ambiental, \\ Universidade do Vale do Itajaí, Escola do Mar, Ciência e Tecnologia, Rua Uruguai 458, \\ Itajaí, SC 88302-901, Brazil; mauromichelena@gmail.com \\ * Correspondence: rafael.avila@furg.br \\ † Current address: UL International GmbH. Ebertstrasse 96, 26382 Wilhelmshaven, Germany.
}

Citation: Ávila, R.A.; Orozco, P.M.S.; Andrade, M.M.; Möller, O.O., Jr. Temporal Variability of Suspended-Solids Concentration in the Estuarine Channel of Patos Lagoon, Southern Brazil. Water 2021, 13, 646. https://doi.org/10.3390/ w13050646

Received: 28 November 2020

Accepted: 14 January 2021

Published: 28 February 2021

Publisher's Note: MDPI stays neutral with regard to jurisdictional clai$\mathrm{ms}$ in published maps and institutional affiliations.

Copyright: (C) 2021 by the authors. Licensee MDPI, Basel, Switzerland. This article is an open access article distributed under the terms and conditions of the Creative Commons Attribution (CC BY) license (https:// creativecommons.org/licenses/by/ $4.0 /)$.

\begin{abstract}
The assessment of suspended-solids dynamics is crucial for the effective monitoring of estuarine environments. As the recurring in-situ sampling is usually problematic, the calibration of the backscattering from acoustic Doppler profilers has shown to be a reliable technique to estimate the suspended-solids concentration (SSC) in estuaries and rivers. In this study, we obtained a linear model that provides SSC estimates for the estuarine channel of Patos Lagoon by calibrating turbidity and acoustic data with in-situ concentration samples. The model output was analyzed in terms of its relationship with estuarine hydrodynamics and temporal variability. In this estuary, the supply of suspended solids is known to be due the runoff from its main tributaries, but also through the exchanges between the estuary and the coastal ocean. Both sources provide sediments and organic solids which affect water quality, geomorphology, and harbor operations. Results show that SSC is strongly linked to estuarine hydrodynamics, where concentrations increase with streamflow. During outflow periods, higher concentrations are associated with river runoff, whereas with inflow conditions they are induced by southern and southwesterly winds. However, relationship between SSC and streamflow is asymmetrical, meaning that the largest concentrations are majorly linked to outflow currents and downstream transport.
\end{abstract}

Keywords: suspended-solids concentration; acoustic signal backscatter; Patos Lagoon estuary; temporal variability

\section{Introduction}

Suspended solids, also known as suspended matter, are a common element of aquatic environments, but they are of particular importance in estuaries. These environments present complex hydrodynamics due to the interaction between fresh and salt waters, usually coupled with the action of tides and winds, often leading to particular patterns of suspended-solid distribution and a considerably larger average concentration when compared to the open ocean. Solid particles in the aquatic environment are mostly composed of organic and inorganic suspended sediments and their concentrations often have implications in water quality (e.g., [1-3]), in the formation of flocculated material in the presence of saltwater [4], leading to zones of maximum turbidity [5] and in estuarine hydrodynamics by altering the geomorphology through erosion, deposition and resuspension (e.g., [6-8]). In addition, the evaluation of suspended solids in estuaries can be of particular interest to dredging operations in harbors and navigation channels (e.g., [1,9]). Therefore, the knowledge of their distribution and variability is essential to achieve a representative study and monitoring of estuarine environments. 
The quantification of the suspended-solids concentration (SSC) in either estuarine or marine environments is performed primarily through in-situ sampling techniques, which are usually time-consuming and logistically difficult. In-situ sampling is perhaps suitable for short-timescale surveys (i.e., few days or weeks), but it is usually problematic for long-timescale studies (i.e., years). It must also be conducted periodically to accurately encompass the suspended-solids variability associated with local hydrodynamics. Given this inherent difficulty, the use of surrogate techniques by means of Acoustic Doppler Profilers (ADPs) is usually more suitable and effective. Because surrogate techniques can provide data quicker (after a suitable calibration is performed), the need for recurring insitu sampling is considerably reduced. The acoustic signal transmitted by these instruments, primarily used to determine particle velocity through the Doppler effect, is subject to backscattering due to suspended solids in the water column [10]. Backscattering is a measure of the spreading and attenuation of the acoustic signal as it travels along the water. It is not only generated by suspended particles, but it also depends on water density and instrument-specific parameters such as frequency, power, transducer size, and slant angle [11]. When taking these factors into consideration, the interaction between suspended solids and the acoustic signal is proportional to their concentration, thus allowing reliable estimates [12].

The application of surrogate techniques to estimate SSC can indeed be very useful, especially in estuaries with rapid changes in hydrodynamics and where the suspended solids come from different sources. The estuary of Patos Lagoon is a good example of a suitable environment for their application. Patos Lagoon is a large coastal lagoon located in southern Brazil, connected to the Atlantic Ocean by a narrow channel in its southern part (Figure 1). This channel is characterized by a circulation system majorly controlled by the river runoff and wind, where the lagoon and the ocean exchange properties within variable timescales [13-15]. Regarding the tidal range in this lagoon, tides show microtidal amplitudes, and although they can drive oscillations due to the combined effect of diurnal tides and sea breeze [16], they are mostly negligible in the channel area.

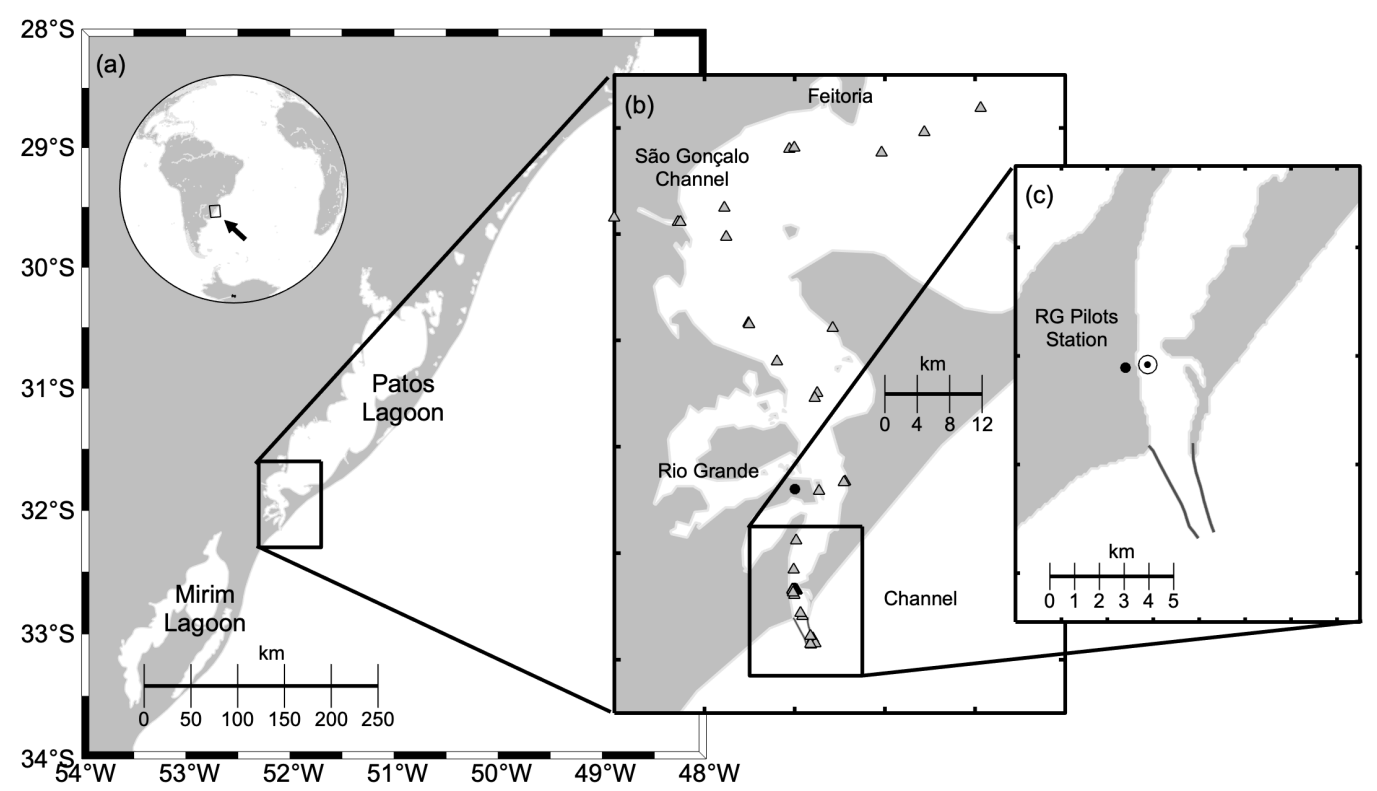

Figure 1. Study site location and survey details. In panel (a) are the location of the Patos-Mirim system and the estuary of Patos Lagoon. In panel (b) is the estuarine area, which is the area from the channel to the location known as Feitoria, with the positions where the in-situ concentration samples were collected (grey triangles). In panel (c) is the location of the Argonaut XR mooring (white and black circle). 
The estuary of Patos Lagoon is of both biological and economic importance since it is a habitat for different species $[17,18]$ and allows access to one of the largest harbors in the country. This estuary has complex geomorphology mainly in its northern part, with small sedimentary islands, shallow bays, and sand spits, with depths varying between 1 and $5 \mathrm{~m}$. The southern part contains natural and artificially-dredged channels ranging from 10 to $18 \mathrm{~m}$ deep, and the connection with the ocean is kept open by two jetties approximately $4 \mathrm{~km}$ long. Earlier studies carried out in the estuary identified that the main source of suspended solids is the river discharge, responsible for carrying organic particles, fine sediments, and sand $[19,20]$. Non-cohesive sediments-such as sand and coarse sand-can be found in shallow, marginal areas, and they are more subject to resuspension due to the intrusion of oceanic waters as well as to the exchanging flows between the estuary and coastal ocean [21]. Fine sediments-mostly silt and clay-are predominant in the deeper parts and bay areas, as their deposition is conditioned to low hydrodynamic and high residence times. The accumulation of fine sediments at the deeper parts of the channel affects harbor operations significantly, requiring periodic dredging to maintain a navigable depth. The characteristics and distribution of suspended solids in the estuary is, in general, similar to the lagoon area. However, their dynamics and transport are highly increased in the estuarine area due to the chocked geomorphology of the channel. During high river discharge periods associated with northeasterly winds, fine sediments deposited in the estuary can be exported towards the ocean in a significant amount [22] and transported along the adjacent coastal area in the form of a coastal plume, generating extensive mud deposits along the adjacent coastal zone, called Patos Facies [23].

These earlier studies in Patos Lagoon provided very relevant information about the general dynamics of the suspended solids, but unfortunately none of them covered a large and continuous-time span (i.e., one year or so). Furthermore, there is no report of any long time monitoring of SSC for this region using in-situ data in recent years. The analysis of long time series provides not only a synoptic view of its variability, but it also shows all possible periodic and extreme oscillations, thus becoming a valuable contribution to all ongoing studies in the estuary of Patos Lagoon. Studies conducted in other estuaries such as [24-28] were capable of evaluating different characteristics and aspects of the local suspended solids by combining SSC time series with hydrological data and remote sensing. These studies also highlighted the inherent difficulty in maintaining and analyzing long time series of environmental data.

In this paper, we present different measurements carried out in the estuary of Patos Lagoon, focusing on a two-year time series of estimated SSC. These measurements were part of the Brazilian Coast Monitoring System (SiMCosta), which has been recently monitoring the impacts of dredging in the estuarine hydrodynamics. The objectives of our study are (1) to provide a linear model to obtain SSC estimates from a moored acoustic device and (2) to analyze the model output in terms of temporal variability, relationship with estuarine hydrodynamics, and export rates of solid material towards the ocean. We describe the field experiment and data used, and results are discussed in terms of statistical evaluation and comparison with in-situ estimates, analysis of data output, and its relationship with estuary hydrodynamics.

\section{Calibration of Optical and Acoustic Data}

The procedure to yield a time series of estimated SSC went through two main steps, which were (1) the calibration of a turbidity sensor using in-situ concentration and (2) the subsequent calibration of the acoustic signal backscatter from a moored instrument using turbidity-estimated concentrations. The calibration of both optical and acoustic data was accomplished using linear regression fitting models evaluated by means of the statistical significance of samples (i.e., quality and quantity), mean absolute and root-mean-square errors (MAE and RMSE, respectively), and determination coefficient $\left(R^{2}\right)$. The fit method used was the "iteratively re-weighted least squares", also called robust fitting [29]. This method was chosen because it is less influenced by possible outliers than the least-squares fitting. 
In-situ SSC were obtained from 152 water samples collected at different points in the Patos Lagoon estuary (see Figure 1 panel (b)) from April, 2014 to May, 2019, during nonperiodic surveys. The samples were taken to the laboratory for filtration with pre-weighed filters of $0.45 \mu \mathrm{m}$ pore size to determine SSC as dry matter mass per unit volume of water $\left(\mathrm{mgL}^{-1}\right)[30]$. These samples were used to calibrate the optical backscatter from a turbidity sensor coupled to a JFE Advantech ${ }^{\mathrm{TM}}$ Rinko-profiler CTD (Conductivity, Temperature, and Depth), which measured turbidity profiles simultaneously to the water samples. To perform the turbidity calibration, care was taken to correctly associate the depths of the in-situ samples with their respective values of turbidity. To collect samples at deeper levels, the bottles were attached to the CTD to accurately determine their depth.

The calibration of a turbidity sensor to estimate SSC is made through a linear regression of the in-situ samples with their concurrent values of turbidity. For most marine and estuarine environments, SSC and turbidity have a positive linear correlation when concentration does not exceed $20 \mathrm{gL}^{-1}$ [31]. Estimates of the SSC derived from turbidity $\left(S S C_{T u r b}\right)$ can be obtained from the linear equation

$$
S S C_{\text {Turb }}=\alpha_{1} \text { Turb }+\beta_{2} \quad\left[\mathrm{mgL}^{-1}\right],
$$

where $\alpha_{1}$ and $\beta_{1}$ are the slope and intercept coefficients, respectively, resulting from the fitting between the in-situ samples and their corresponding values of turbidity.

Once the optical sensor was calibrated, we used the turbidity-estimated concentrations to calibrate the acoustic signal backscattering from a 1500-kHz SonTek ${ }^{\mathrm{TM}}$ Argonaut XR (SonTek/YSI, San Diego, CA, USA), moored in the main channel at the lower estuary (see Figure 1 panel (c)). It was deployed on 10 August 2018 at approximately $16 \mathrm{~m}$ deep, and has measured data continuously ever since at a 30-min average interval. The uplooking device uses three transducers for 3D velocity measurements (X/East, $Y$ /North and $Z / \mathrm{Up}$ ) with a slant angle of $25^{\circ}$ [32]. Although it primarily measures current velocity, the device also provides raw signal amplitude as a standard output variable (stored in a logarithmic unit called counts), and is equipped with pressure and temperature sensors. The instrument was configured to measure within 10 cells of $1.5 \mathrm{~m}$ each plus $1 \mathrm{~m}$ of blank distance, hence covering a vertical distance of up to $16 \mathrm{~m}$. This configuration was chosen to avoid measurements too close to the transducer and to compensate for the level variations. In post-processing, the Argonaut XR compass was corrected according to the local magnetic declination, and all spurious data-such as spiked values and bad records due to sensor faults and biological fouling-were removed after statistical control and visual inspection.

To perform the calibration of the acoustic data we collected turbidity at the Argonaut XR mooring location in a field survey conducted between 15 and 17 February 2019. During the three-day survey, we launch the CTD 36 times above the position of the moored device to obtain turbidity profiles, which were used to obtain SSC estimates to calibrate the Argonaut XR acoustic signal backscattering. The corresponding acoustic data-measured at a 30-min average interval-were extracted according to the time (i.e., hour and minute) of each CTD profile. The acoustic data measured within the last cell (i.e., closest to the surface) were not included in the calibration as they may result into spiked/spurious data due to side-lobe effects, generated by near-boundary measurements [32]. As the CTD data had a much higher spatial resolution $(10 \mathrm{~cm}$ on average), they were interpolated into a regular grid of ten vertical levels to match the Argonaut XR measurement range and cell size.

Acoustic backscattering $(\mathrm{AB})$ is a measure of the corrected and range-normalized signal amplitude. This correction is made based on the predicted two-way transmission losses due to geometric spreading and attenuation by water and suspended solids, using an adaptation of the sonar equation from [33] proposed by [34] as

$$
A B=10 \log _{10}\left(10^{K E / 10}-10^{K E_{r} / 10}\right)+20 \log _{10}(R)+2 \alpha_{w} R+2 \alpha_{s} R \quad[\mathrm{~dB}],
$$


where $E$ is the raw signal amplitude measured by the acoustic profiler and $E_{r}$ is the reference-or noise-level, both in counts, and $K$ is a scale factor used to convert counts to $\mathrm{dB}$, ranging from 0.35 to 0.55 according to the instrument specification [10]. For Sontek ${ }^{\mathrm{TM}}$, a value of 0.43 is recommended [35]. The term $20 \log _{10}(R)$ represents the decaying of the acoustic signal due to geometric spreading along the measurement range $(R)$, which represents the spatial distance covered by the acoustic signal along the water column. It must incorporate the slant angle of the transducer, resulting in $R=R \cos (\phi)^{-1}$. The coefficients $\alpha_{w}$ and $\alpha_{s}$ represent the attenuation of the acoustic signal due to water and to suspended solids, respectively. The former is a function of the instrument acoustic frequency and water density [36] and was calculated using the equation from [37]. The latter is a function of the characteristics and quantity of the suspended solids of the study site, and its calculation requires knowledge on several parameters such as particle size and density of the suspended material as well as factors such as the frequency of the acoustic wave and water density $[38,39]$. The coefficient $\alpha_{s}$ increases with acoustic frequency, albeit the importance of $\alpha_{s}$ over $\alpha_{w}$ decreases considerably at concentrations lower than $200 \mathrm{mgL}^{-1}$ [40]. We were not able to determine $\alpha_{w}$ precisely, as most information required for its calculation was unavailable. Instead, we used an estimate based on the average concentration of the in-situ samples $\left(<100 \mathrm{mgL}^{-1}\right)$, an estimated particle diameter between $4 \mu \mathrm{m}$ and $63 \mu \mathrm{m}[20,41]$, and the acoustic frequency of the Argonaut XR. According to Figure 1 in [40], a maximum ratio of $\alpha_{s} / \alpha_{w}$ of 0.5 is reached when applying the aforementioned parameters. Therefore, we used $\alpha_{S}$ as $\alpha_{w} / 2$. By taking those factors into account, AB-estimated concentration $\left(S S C_{A B}\right)$ can be obtained through the exponential equation

$$
S S C_{A B}=10^{\left[\alpha_{2} A B+\beta_{2}\right]}\left[\mathrm{mgL}^{-1}\right],
$$

where $\alpha_{2}$ and $\beta_{2}$ are the slope and intercept coefficients, respectively, resulting from the linear regression between the concentrations and their concurrent $A B$ in a semi-log plane [12].

\section{Calibration Results}

\subsection{Turbidity Sensor Calibration}

Turbidity showed a good linear response to the in-situ SSC (Figure 2), with a determination coefficient of $R^{2}=0.94$ at $95 \%$ of confidence. The resulting equation is

$$
S S C_{\text {Turb }}=1.612 \text { Turb }+1.2487\left[\mathrm{mgL}^{-1}\right] .
$$
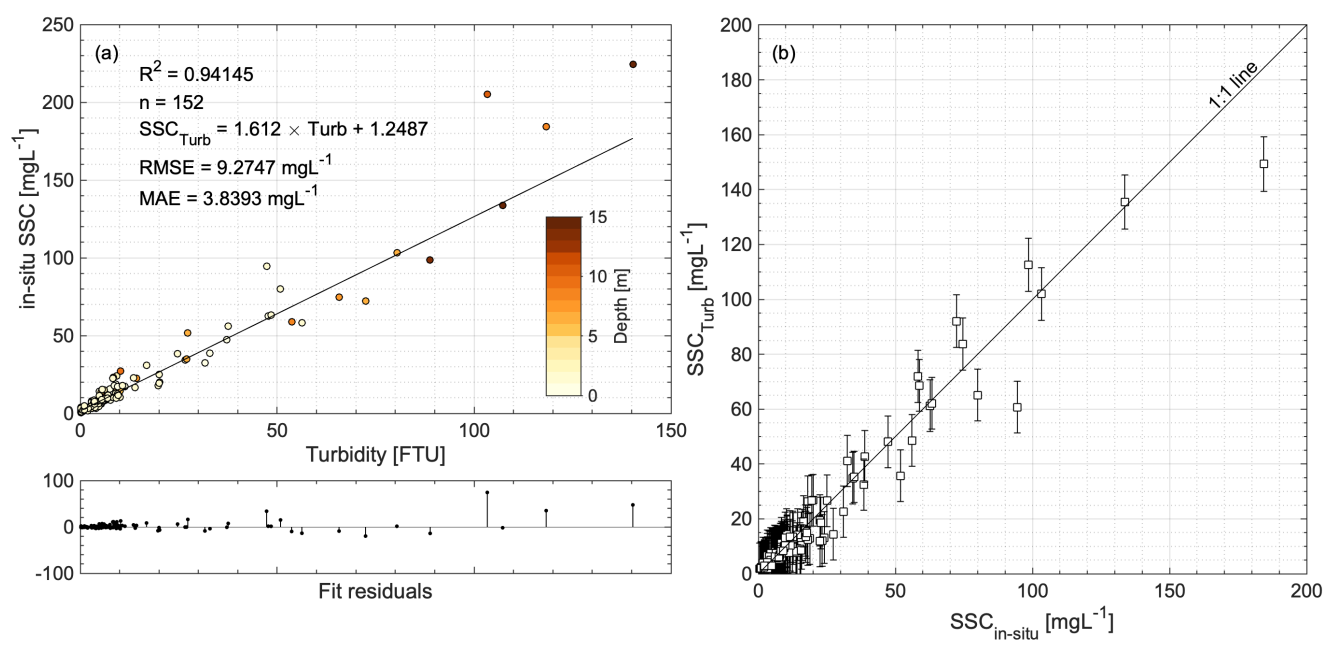

Figure 2. In panel (a) is shown the linear regression between the in-situ concentrations and their concurrent turbidity values measured with the optical sensor of the CTD, with the respective fit residuals. In panel (b) is the comparison between the in-situ suspended-solids concentration (SSC) with the turbidity-estimated SSC with their respective 95\% confidence interval. 
Both MAE and RMSE are relatively low, and, because the in-situ SSC are mostly under $50 \mathrm{mgL}^{-1}$, the model provides better estimates at lower concentrations as the residuals and confidence intervals are clearly reduced at this concentration range.

\subsection{Acoustic Signal Backscattering Calibration}

The conditions observed during the three-day field survey to collect turbidity data for the calibration of the acoustic data are displayed as ensemble averages of streamflow velocity, $A B$, salinity, and turbidity profiles (Figure 3). Only the $Y / N$ velocity component is shown because of the North-South orientation of the channel, where negative values represent the southward direction (i.e., outflow). The hydrodynamics were marked by relatively strong currents, with surface velocities reaching up to $0.7 \mathrm{~ms}^{-1}$ on average. A pronounced salinity stratification was observed, varying from around 10 at the surface to near 30 at the bottom of the channel. Turbidity was considerably low close to the surface ( $\sim 5$ FTU), but it exponentially raised towards the bottom, a pattern also followed by the backscattering. Overall, these conditions characterize a transition from estuarine inflow to outflow.
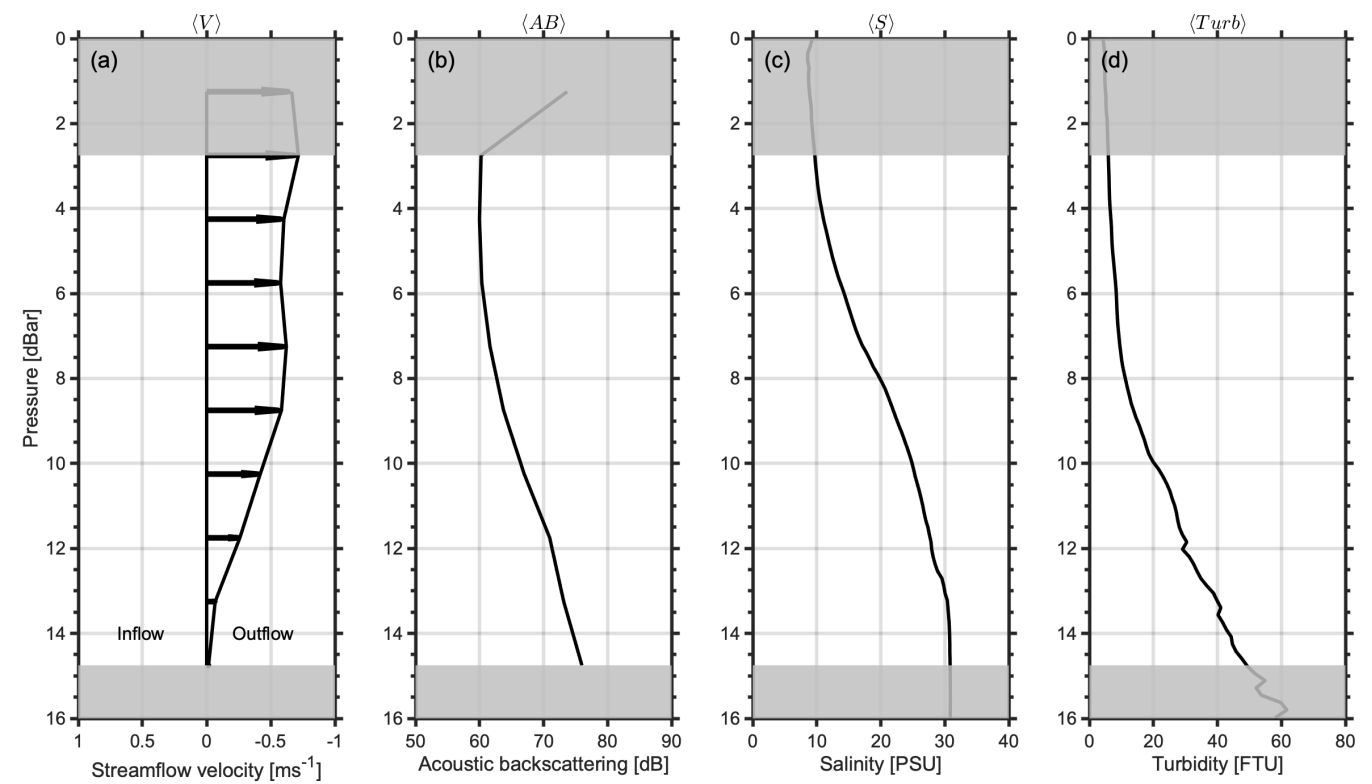

Figure 3. Average conditions observed during the three-day field experiment to calibrate the acoustic data. In (a) is the $Y / \mathrm{N}$ current velocity component, in (b) is the acoustic backscatter, in (c) is salinity and in (d) is turbidity. As the estuarine channel is mainly North-South-oriented, the $Y$ / N component corresponds to its streamflow. Each profile is an ensemble average of 36 vertical profiles obtained during the three-day survey. Negative and positive velocities represent the direction of outflow and inflow, respectively. The data within the grey shades were not included in the calibration.

The $\mathrm{AB}$ showed an adequate linear response to the $\log _{10}$ of the turbidity-estimated concentrations (Figure 4 ), with a determination coefficient of $\mathrm{R}^{2}=0.76$ at $95 \%$ of confidence. The resulting equation is

$$
S S C_{A B}=10^{[(0.0611 A B)-3.8073]}\left[\mathrm{mgL}^{-1}\right] .
$$

Similar to the turbidity calibration, this model provides better estimates at lower concentrations. Both MAE and RMSE are slightly higher when compared to the turbidity calibration, as well as the confidence interval of concentrations estimates above $50 \mathrm{mgL}^{-1}$. 

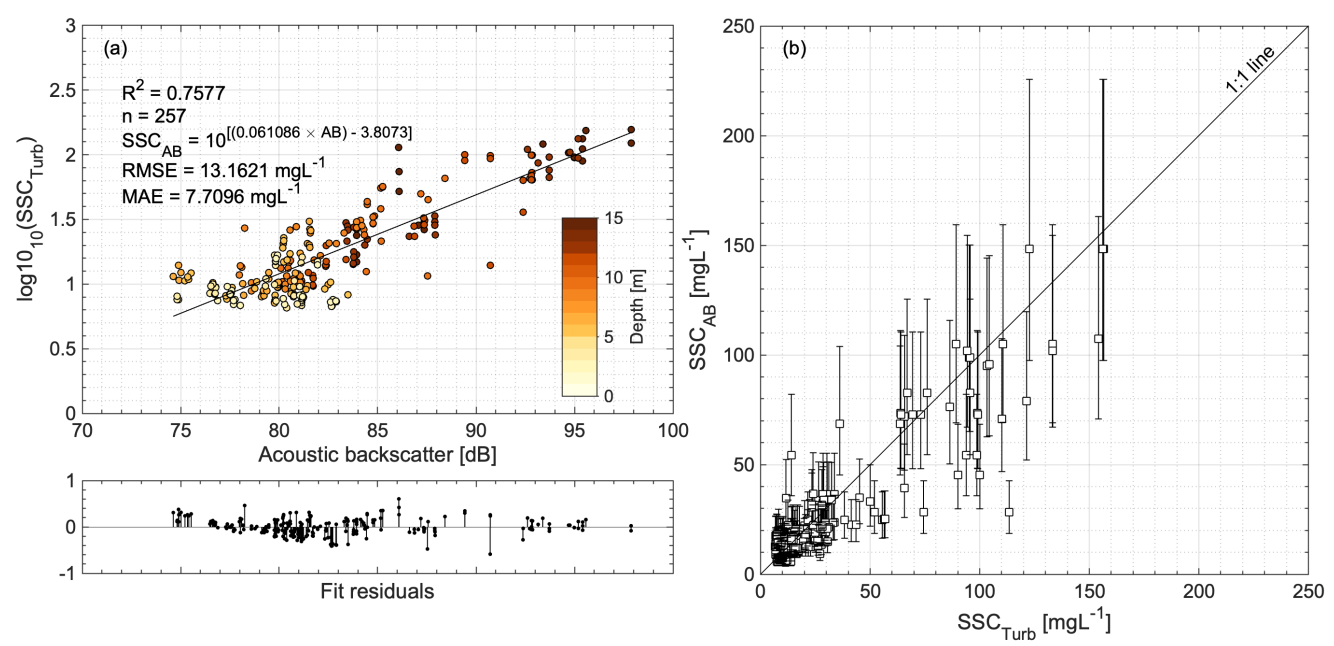

Figure 4. In panel (a) is shown the linear regression between the $\log _{10}$ of the turbidity-estimated concentrations with their concurrent measured acoustic backscattering (AB), with the respective fit residuals. In panel (b) is the comparison between the in-situ SSC with the turbidity-estimated SSC with their respective $95 \%$ confidence interval.

\section{Analysis of output Data from the AB Model}

Now we analyze the output from Equation (5) by obtaining a time series of SSC estimated from the Argonaut XR acoustic data. A time series of $\mathrm{AB}$ was obtained using Equation (2), where $\alpha_{w}$ was calculated by using pressure and temperature from the Argonaut XR sensors. Because there was no salinity time series available for this location during the deployment period, a fixed value of 19 was used to calculate $\alpha_{w}$. This value corresponds to the temporal average of a 10-year (2003-2013) bottom salinity dataset previously measured near the mooring site. As explained earlier, $\alpha_{s}$ was estimated to be $\alpha_{w} / 2$.

The two-year time series can be seen in Figure 5. The concentrations are shown as averages from the surface, middle, and bottom cells, along with hourly wind velocity from the Rio Grande Pilots Station, water level, and depth-integrated streamflow velocity $(\bar{V})$. Data from the closer-to-surface cell were not included in the analysis because of the larger uncertainties associated with near-boundary measurements. As the transport of properties such as suspended sediments and larvae in the Patos Lagoon estuary are more subject to the subtidal circulation $[16,42,43]$, the time series were filtered with a 24-h low-pass cosine filter to remove most of the short-period oscillations and interpolated into the same sample interval of $\Delta t=60 \mathrm{~min}$.

We choose four distinct periods to analyze the behavior of the AB-estimated SSC according to changes in wind, streamflow, and water level. These periods were selected based on the magnitude of these forcings and their associated peaks of concentration. The SSC shows a temporal variability highly associated with estuarine streamflow. In general, peaks of concentration are linked to stronger outflow currents, as the downstream transport induced by the higher river discharge leads to a larger input of suspended-solids in the estuary. These peaks are related to increasing outflow and reduced water level, as occurred in September 2018 and October 2019 (blue shades in Figure 5, namely P1 and P3). During austral spring and winter months, Patos Lagoon has higher river discharge from its main tributaries - namely the Guaíba and Camaquã rivers, and the São Gonçalo Channel-due to higher rainfall rates in the south region of Brazil $[13,44]$. This relation between river discharge and SSC was recently observed in a modeling study from [45], where a strong correlation between these time series was found. However, although most of the peaks of SSC are related to outflow, the time series also presents peaks associated with inflow currents, as occurred in July 2019 and April 2020 (red shades in Figure 5, 
namely P2 and P4). During these periods, an increase in southern and southwesterly wind speeds and a water level rise can be observed.

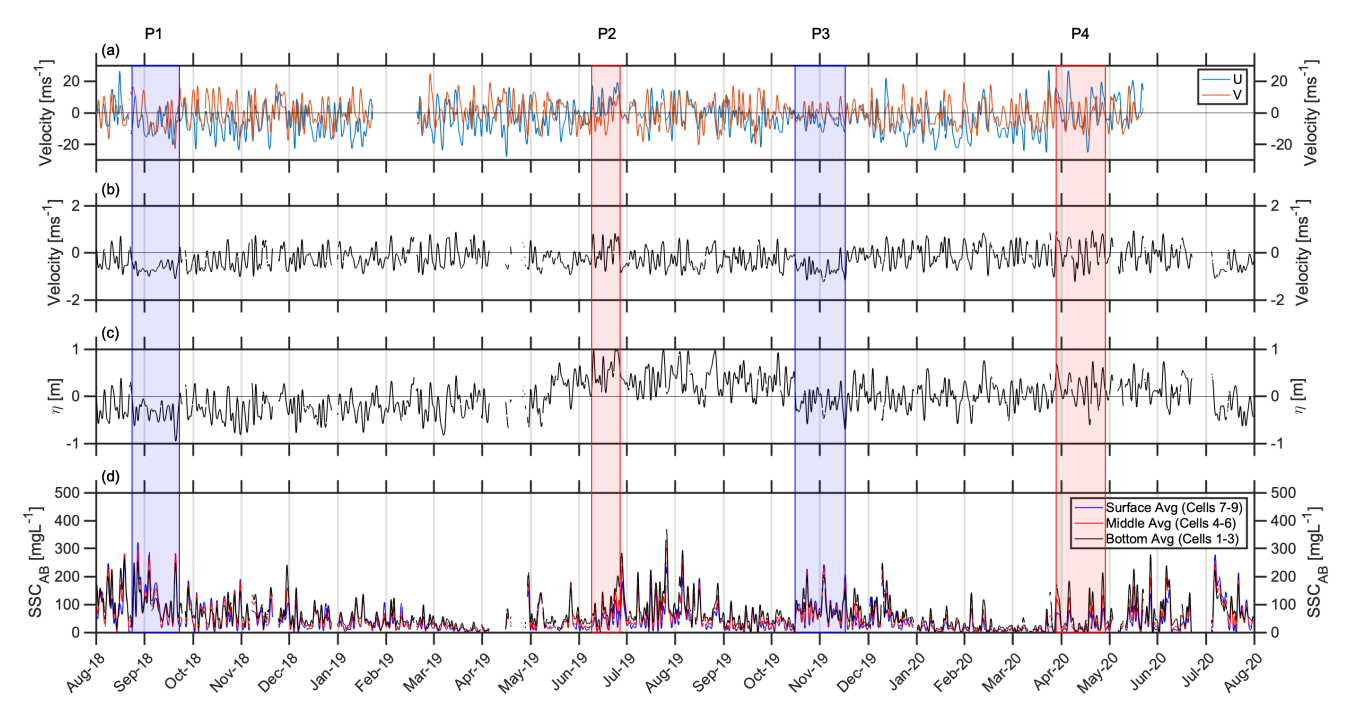

Figure 5. Time series of (a) zonal (U) and meridional (V) wind velocity measured at the RG Pilots station, (b) depth-integrated streamflow velocity $(\bar{V})$ and (c) water level $(\eta)$, both measured by the Argonaut $\mathrm{XR}$, and surface, middle, and bottom average concentrations estimated by the acoustic signal backscattering from the Argonaut XR. The blue and red shades are periods of increased outflow and inflow chosen for analysis (P1, P2, P3, and P4). Positive values represent the eastward and northward direction in (a) and northward in (b).

Although the Patos Lagoon estuary hydrodynamics is mainly driven by the river discharge, it is reported to be controlled by winds during periods of low-to-moderate discharge, which is usually under $3000 \mathrm{~m}^{3} \mathrm{~s}^{-1}$ [46]. Southwesterly or northeasterly winds along the coast are able to increase significantly the estuarine inflow and outflow, respectively. The relationship between SSC in the estuarine channel and the streamflow and wind is better seen with a cross-correlation analysis (Figure 6). The results show a smaller influence of the wind during the outflow periods and a strong correlation between outflow currents (i.e., negative values) and the rise in concentration. During inflow, on the other hand, the streamflow is strongly correlated with the wind, especially during P2, but the response of the concentration to streamflow is significantly reduced. This suggests that the increase in SSC during inflow was not solely generated by stronger currents that led to the resuspension of non-cohesive material settled in the channel area. The lower outflow coupled with southern and/or southwesterly winds leads to saltwater intrusion in the estuary, which is favorable to the aggregation and flocculation of fine material and, consequently, to the increase in concentration in the channel. The studies from [22,47] reported that saltwater intrusion may cause resuspension of non-cohesive material and lead to the flocculation of fine sediments, leading to higher SSC in the estuary. It is also possible that the increase in SSC in the channel is linked to the transport of non-cohesive material from the coastal zone-mostly coarse sand. The Patos Lagoon coastal zone is subject to the action of storm surges associated with the passage of cold meteorological fronts and strong southern winds. These events are able to increase inflow velocities significantly and cause alterations in the channel geomorphology [48]. However, sediment transport due to storm surges is usually restricted to the jetties area and coastal zone. 

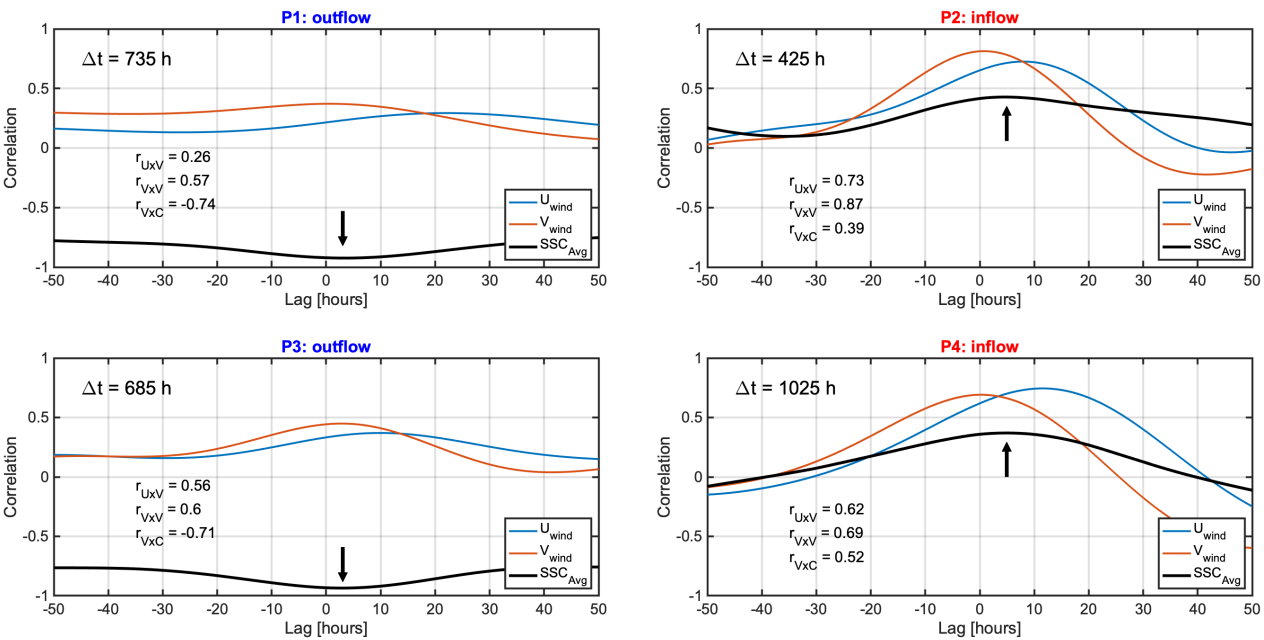

Figure 6. Cross-correlation analysis between zonal (U) and meridional (V) winds and streamflow (blue and red lines) and between streamflow and depth-averaged SSC (thick black line) during outflow (P1 and P3) and inflow events (P2 and P4). The number of hours ( $\Delta t)$ of each event is displayed, as well as the Pearson's coefficient of each correlation. The black arrow highlights the points of greater correlation between streamflow and concentration.

Results show that the intensification of both inflow and outflow currents increases the average concentrations in the channel area. However, the SSC distribution according to velocity shows an asymmetrical shape where larger concentrations are clearly linked to outflow currents and downstream transport due to higher river discharge (Figure 7, panel a). Furthermore, the increase in the bottom concentration relative to the vertical average occurs slightly more often during inflow rather than outflow (Figure 7, panel b). This larger bottom concentration relative to the vertical average is most likely associated with the resuspension of settled material. Although the intensification of inflow currents clearly leads to higher bottom concentration, our data do not allow us to quantify precisely how much of this increase is associated with resuspension or flocculation due to saltwater intrusion.
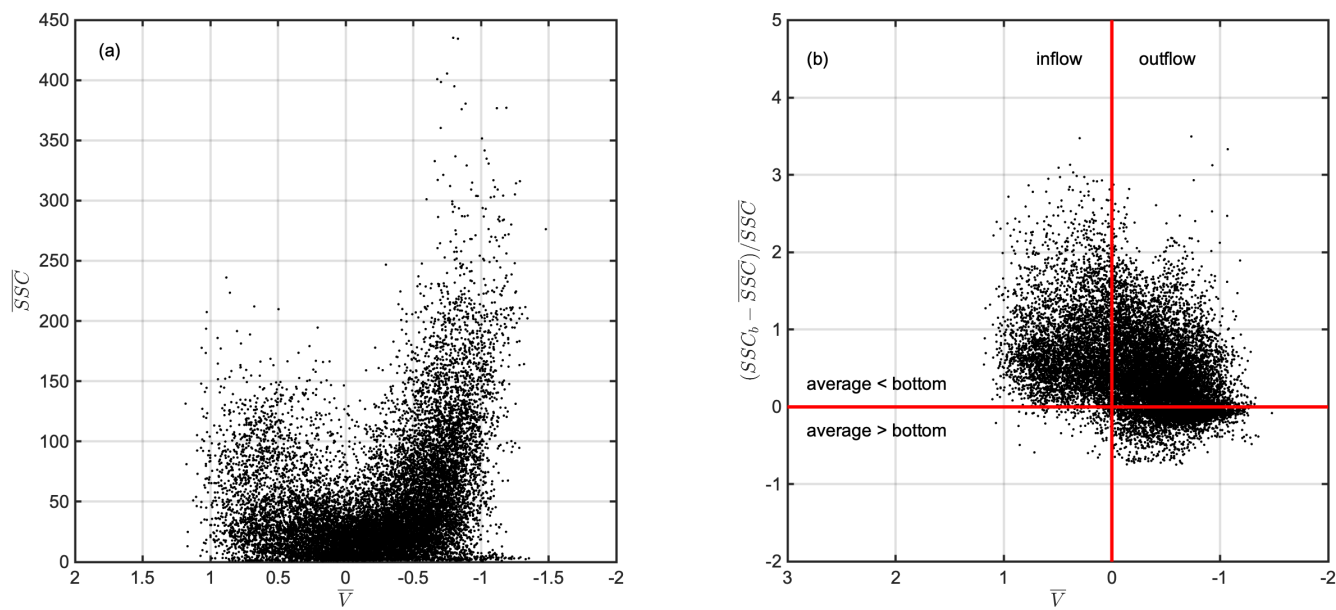

Figure 7. In (a) is shown the relation of the depth-averaged streamflow $(\bar{V})$ to their associated values of depth-averaged concentration $(\overline{S S C})$; in (b) is the relation of $\bar{V}$ to the relative difference between bottom concentration $\left(S S C_{b}\right)$ to $\overline{S S C}$. Positive values of $\bar{V}$ represent inflow.

Monthly averages of streamflow velocity $\left(\overline{V_{m}}\right)$ and AB-estimated concentrations $\left(\overline{S S C_{m}}\right)$ were obtained to calculate estimated values of river discharge $(Q)$ and exportation of solid material $(E)$ during the Argonaut XR deployment period (Figure 8). These 
averages were calculated to remove short-time variabilities mainly related to local wind and meteorological fronts and only keep the oscillations associated with seasonality. River discharge in cubic meters per second was calculated as $Q=\overline{V_{m}} A$, where $A$ is an approximate area of the channel section. Considering level variations, this area is estimated to vary between 10,000 and $11,000 \mathrm{~m}^{2}$. To determine $Q$, only the downstream flow was considered in the calculation. Exportation of solid material was determined by $E=\int_{0}^{T}\left(\overline{S S C_{m} V_{m}} A\right) d t$, resulting in averages of exported material in tons per month (see chapter 5 in [49]).

The data highlights the periods of higher river discharge and increased estuarine outflow which lead to larger SSC during spring and winter months such as P1 and P3. During these periods, the average velocity profiles are vertically uniform, with average outflow currents reaching up to $1 \mathrm{~ms}^{-1}$ at the surface. On the other hand, discharge is considerably reduced during summer and fall and averages stay under $3000 \mathrm{~m}^{3} \mathrm{~s}^{-1}$, allowing hydrodynamics to be mainly controlled by the wind, as it occurs during P2 and P4. These conditions eased the upstream transport by allowing southern and southwesterly winds to push oceanic water into the channel, reducing the streamflow average velocity significantly, and leading to an increase in the average SSC. During the two-year period, a total estimate of $10.75 \times 10^{6}$ tons of material was exported towards the ocean, with a monthly average of $4.31 \times 10^{5}$ tons. Our estimates are close to the values found in a recent study from [50], where the authors estimated a contribution from the main tributaries of approximately $5.1 \times 10^{6}$ ton $\mathrm{yr}^{-1}$.

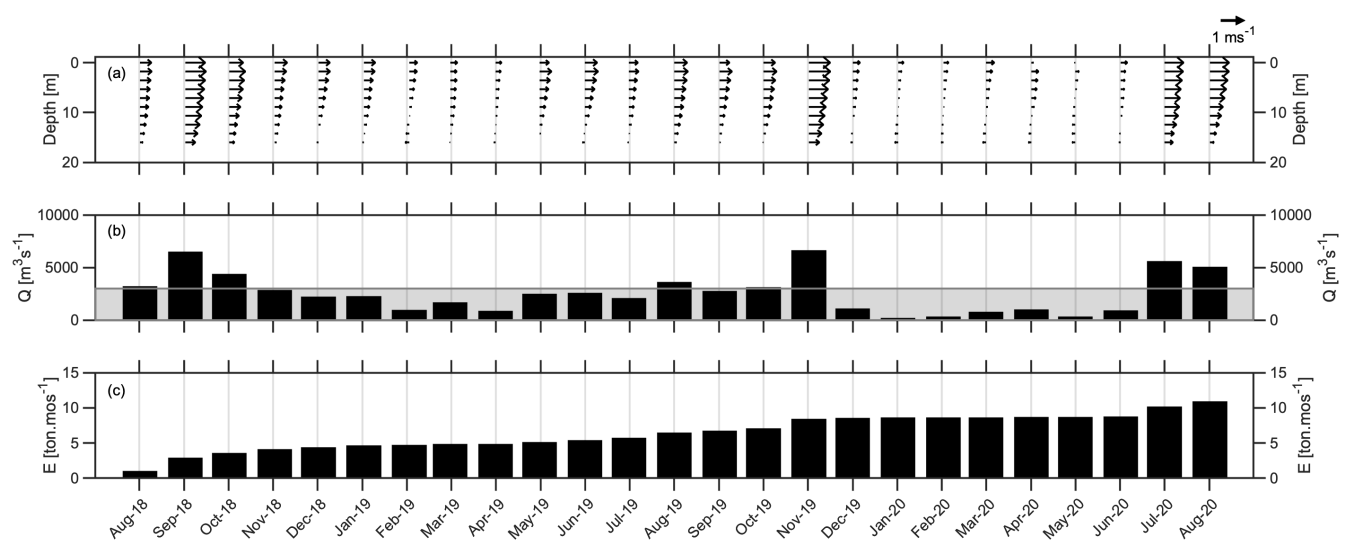

Figure 8. In (a) is the monthly-averaged velocity profiles, in (b) is the estimated monthly-averaged river discharge, and (c) is the accumulated exportation of solid material towards the ocean during the entire period, in tons per month. The grey shade in $(\mathbf{b})$ is the threshold of wind action influence upon the channel hydrodynamics. Above this, the river runoff majorly controls the circulation.

\section{Concluding Remarks}

Overall, both models yielded satisfactory outcomes, resulting in estimated concentrations that showed good agreement in-situ SSC and relatively low statistical error. Better estimates were observed mostly at concentrations under $50 \mathrm{mgL}^{-1}$, since the in-situ samples seldom surpassed this value during the sampling period. Thus, both models are a good representation of the SSC magnitude found in the recent surveys carried out in the estuary. However, more data must be included in both calibrations to better incorporate the seasonal variability in SSC and hence provide a more reliable and robust model. Furthermore, it is important to mention that the application of surrogate methods to determine concentration cannot reproduce entirely the magnitude and variability of suspended solids in the environment. They must be used as an additional tool to provide a quick overview of the suspended-solids characteristics to aid monitoring surveys, environmental studies, and dredging operations, specially for long time periods. Furthermore, surrogate techniques need to be complemented with eventual in-situ samplings when possible. 
Results show that the SSC variability in the Patos Lagoon estuarine channel has a strong association with hydrodynamics evidenced by the increase in concentrations with streamflow, which is more pronounced during outflow. It is a system mainly controlled by freshwater runoff, and the chocked shape of the channel strongly intensifies outflow currents at high river discharge. On the other hand, increased SSC was also associated with estuarine inflow, suggesting that the material settled in the channel are susceptible to resuspension due to both stronger inflow and outflow currents. There is evidence of high SSC linked to inflow, albeit our data do not allow us to evaluate or quantify how much of this increase is linked to flocculation, resuspension or material transported from the costal zone into the channel. However, based on previous studies in the area, the first two hypotheses seem to be more likely.

The dynamics of suspended solids in the estuary of Patos Lagoon is, in general, wellknown thanks to the efforts of earlier surveys. Nevertheless, the present study provides a two-year, nearly continuous view of the suspended-solids variability in the estuarine channel, which brings out the novelty of our research. Our results provide the observation and analysis of periodic events and a quantitative linkage between concentration in the channel and changes in the magnitude and direction of the streamflow and wind. We hope our findings represent a relevant contribution to the overall knowledge on the suspendedsolids dynamics in the estuary of Patos Lagoon and, more importantly, motivate further similar studies.

Author Contributions: Methodology, investigation and data analysis: R.A.Á. and P.M.S.O.; writingoriginal draft preparation: R.A.Á., P.M.S.O. and M.M.A.; writing—review and editing: all authors; supervision and project administration: O.O.M.J. All authors have read and agreed to the published version of the manuscript.

Funding: This study was funded by "Projeto de monitoramento do sítio de despejo e área adjacente do material dragado do canal de acesso ao porto de Rio Grande" (788-PO-18), part of the Brazilian Coast Monitoring System (SiMCosta-http:/ / www.simcosta.furg.br/, accessed on 20 October 2020).

Institutional Review Board Statement: Not applicable.

Informed Consent Statement: Not applicable.

Data Availability Statement: All data used in this study may be available under request to O.O.M.J.

Acknowledgments: The authors would like to thank the SiMCosta crew and the technicians involved in the surveys and data collection. The Argonaut XR is moored in the estuary thanks to a partnership between Universidade Federal do Rio Grande and Rio Grande Pilots Station. This partnership also provided the meteorological data used in this study.

Conflicts of Interest: The authors declare no conflict of interest.
Abbreviations
The following abbreviations are used in this manuscript:
SSC Suspended Solids Concentration
$\mathrm{AB} \quad$ Acoustic Backscattering
CTD Conductivity, Temperature, and Depth
SiMCosta Brazilian Coast Monitoring System

\section{References}

1. Ruffin, K.K. The Persistence of Anthropogenic Turbidity Plumes in a Shallow Water Estuary. Estuar. Coast. Shelf Sci. 1998, 47, 579. [CrossRef]

2. Turner, A.; Millward, G.E. Suspended Particles: Their Role in Estuarine Biogeochemical Cycles. Estuar. Coast. Shelf Sci. 2002, 55, 857-883. [CrossRef]

3. Devlin, M.J.; Barry, J.; Mills, D.K.; Gowen, R.J.; Foden, J.; Sivyer, D.; Tett, P. Relationships between suspended particulate material, light attenuation and Secchi depth in UK marine waters. Estuar. Coast. Shelf Sci. 2008, 79, 429-439. [CrossRef]

4. Eisma, D. Flocculation ad deflocculation os suspended matter in estuaries. Neth. J. Sea Res. 1986, 20, 113-125. [CrossRef] 
5. Postma, H. Sediment transport and sedimentation in the estuarine environment. In Estuaries; Lauff, G.H., Ed.; American Association for the Advancement of Science: Washington, DC, USA, 1967; pp. 158-179.

6. Bartholdy, J. Transport of suspended matter in a bar-built Danish estuary. Estuar. Coast. Shelf Sci. 1984, 18, 527-541. [CrossRef]

7. Woodruff, J.D.; Geyer, W.R.; Sommerfield, C.K.; Driscoll, N.W. Seasonal variation of sediment deposition in the Hudson River estuary. Mar. Geol. 2001, 179, 105-119. [CrossRef]

8. Perillo, G.M.E.; Pérez, D.E.; Piccolo, C.M.; Palma, E.D.; Cuadrado, D.G. Geomorphologic and physical characteristics of a human impacted estuary: Quequén Grande River Estuary, Argentina. Estuar. Coast. Shelf Sci. 2005, 62, 301-312. [CrossRef]

9. Thomas, C.G.; Spearman, J.R.; Turnbull, M.J. Historical morphological change in the Mersey Estuary. Cont. Shelf Res. 2002, 22, 1775-1794. [CrossRef]

10. Deines, K.L. Backscatter estimation using Broadband acoustic Doppler Current Profilers. In Proceedings of the IEEE Sixth Working Conference on Current Measurement, San Diego, CA, USA, 11-13 March 1999; pp. 1-5. [CrossRef]

11. Thorne, P.; Vincent, C.; Hardcastle, P.; Rehman, S.; Pearson, N. Measuring suspended sediment concentrations using acoustic backscatter devices. Mar. Geol. 1991, 98, 7-16. [CrossRef]

12. Gartner, J.W. Estimation of Suspended Solids Concentrations Based on Acoustic Backscatter Intensity: Theoretical Background. In Proceedings of the Turbidity and Other Sediment Surrogates Workshop, Reno, NV, USA, 30 April 30-2 May 2002.

13. Möller, O.O.; Lorenzzentti, J.A.; Stech, J.L.; Mata, M.M. The Patos Lagoon summertime circulation and dynamics. Cont. Shelf Res. 1996, 16, 335-351. [CrossRef]

14. Fernandes, E.H.L.; Dyer, K.R.; Möller, O.O.; Niencheski, L.F.H. The Patos Lagoon hydrodynamics during an El Niño event (1998). Cont. Shelf Res. 2002, 22, 1699-1713. [CrossRef]

15. Fernandes, E.H.L.; Mariño-Tapia, I.; Dyer, K.R.; Möller, O.O. The attenuation of tidal and subtidal oscillations in the Patos Lagoon estuary. Ocean Dyn. 2004, 54, 348-359. [CrossRef]

16. Möller, O.O.; Castaing, P.; Fernandes, E.H.L.; Lazure, P. Tidal frequency dynamics of a southern Brazil coastal lagoon: Choking and short period forced oscillations. Estuaries Coasts 2007, 30, 311-320. [CrossRef]

17. Martins, I.M.; Dias, J.M.; Fernandes, E.H.L.; Muelbert, J.H. Numerical modelling of fish eggs dispersion at the Patos Lagoon estuary-Brazil. J. Mar. Syst. 2007, 68, 537-555. [CrossRef]

18. Möller, O.O.; Castello, J.P.; Vaz, A.C. The Effect Of River Discharge and Winds on the Interannual Variability of the Pink Shrimp Farfantepenaeus Paulensis Prod. Patos Lagoon. Estuaries Coasts 2009, 32, 787-796. [CrossRef]

19. Hartmann, C.; Harkot, P.F.C. Influência Do Canal São Gonçalo No Aporte De Sedimentos Para O Estuário Da Laguna Dos Patos-Rs. Rev. Bras. Geociências 1990, 20, 329-332. [CrossRef]

20. Calliari, L.J.; Winterwerp, J.C.; Fernandes, E.H.L.; Cuchiara, D.; Vinzon, S.B.; Sperle, M.; Holland, K.T. Fine grain sediment transport and deposition in the Patos Lagoon-Cassino beach sedimentary system. Cont. Shelf Res. 2009, 29, 515-529. [CrossRef]

21. Hartmann, C.; Calliari, L.J. Composição e qualidade do material em suspensão durante alta turbidez na extremidade sul da Laguna dos Patos, RS, Brasil. Pesqui. Geociências 1996, 22, 74-83. [CrossRef]

22. Hartmann, C.; Schettini, C.A.F. Aspectos Hidrológicos Na Desembocadura Da Laguna Dos Patos, RS. Rev. Bras. Geociências 1991, 21,371-377. [CrossRef]

23. Martins, L.R.; Urien.; C.M.; Eichler, B. Distribuição dos sedimentos modernos da plataforma continental sul-brasileira e uruguaia. In Proceedings of the Congresso Brasileiro de Geologia, Curitiba, Brazil, 30 October-4 November 1967; pp. $29-43$.

24. Grabemann, I.; Krause, G. On different time scales of suspended matter dynamics in the Weser estuary. Estuaries 2001, 24, 688-698. [CrossRef]

25. Chen, M.S.; Wartel, S.; Van Eck, B.; Van Maldegem, D. Suspended matter in the Scheldt estuary. Hydrobiologia 2005, 540, 79-104. [CrossRef]

26. Kitheka, J.U.; Obiero, M.; Nthenge, P. River discharge, sediment transport and exchange in the Tana Estuary, Kenya. Estuar. Coast. Shelf Sci. 2005, 63, 455-468. [CrossRef]

27. Li, P.; Ke, Y.; Bai, J.; Zhang, S.; Chen, M.; Zhou, D. Spatiotemporal dynamics of suspended particulate matter in the Yellow River Estuary, China during the past two decades based on time-series Landsat and Sentinel-2 data. Mar. Pollut. Bull. 2019, 149, 110518. [CrossRef] [PubMed]

28. Guo, J.; Ma, C.; Ai, B.; Xu, X.; Huang, W.; Zhao, J. Assessing the Effects of the Hong Kong-Zhuhai-Macau Bridge on the Total Suspended Solids in the Pearl River Estuary Based on Landsat Time Series. J. Geophys. Res. Ocean. 2020, 125, e2020JC016202. [CrossRef]

29. Press, W.H.; Flannery, B.P.; Teukolsky, S.A.; Vetterling, W.T. Numerical Recipes; Cambridge University Press: Cambridge, UK, 1989; p. 702.

30. Loring, D.H.; Rantala, R.T.T. Manual for the geochemical analyses of marine sediments and suspended particulate matter. Earth-Sci. Rev. 1992, 32, 235-283. [CrossRef]

31. Bunt, J.A.C.; Larcombe, P.; Jago, C.F. Quantifying the response of optical backscatter devices and transmissometers to variations in suspended particulate matter. Cont. Shelf Res. 1999, 19, 1199-1220. [CrossRef]

32. Sontek/Yellow Spring Instruments. Argonaut Acoustic Doppler Current Meter Technical Documentation; SonTek/YSI: San Diego, CA, USA, 2001.

33. Urick, R.J. Principles of Underwater Sound, 2nd ed.; McGraw-Hill: New York, NY, USA, 1975. 
34. Gostiaux, L.; van Haren, H. Extracting meaningful information from uncalibrated backscattered echo intensity data. J. Atmos. Ocean. Technol. 2010, 27, 943-949. [CrossRef]

35. SonTek. Sontek Doppler Current Meters - Using Signal Strength Data To Monitors Suspended Sediment Concentration. In SonTek Application Notes; Sontek/YSI: San Diego, CA, USA, 1997.

36. Francois, R.E.; Garrison, G.R. Sound absorption based on ocean measurements. Part II: Boric acid contribution and equation for total absorption. J. Acoust. Soc. Am. 1982, 72, 1879-1890. [CrossRef]

37. Ainslie, M.A.; McColm, J.G. A simplified formula for viscous and chemical absorption in sea water. J. Acoust. Soc. Am. 1998, 103, 1671-1672. [CrossRef]

38. Thorne, P.D.; Hanes, D.M. A review of acoustic measurement of small-scale sediment processes. Cont. Shelf Res. 2002, 22, 603-632 [CrossRef]

39. Gartner, J.W. Estimating suspended solids concentrations from backscatter intensity measured by acoustic Doppler current profiler in San Francisco Bay, California. Mar. Geol. 2004, 211, 169-187. [CrossRef]

40. Park, H.B.; Lee, G.H. Evaluation of ADCP backscatter inversion to suspended sediment concentration in estuarine environments. Ocean Sci. J. 2016, 51, 109-125. [CrossRef]

41. Antiqueira, J.A.F.; Calliari, L.J. Características sedimentares da desembocadura da Laguna dos Patos. Gravel 2005, 3, 39-46.

42. Castello, J.P.; Möller, O.O. On the relationship between rainfall and shrimp production in the estuary of the Patos Lagoon (Rio Grande do Sul, Brazil). Atlântica 1993, 3, 67-74.

43. Calliari, L.J.; Facchin, S. Laguna dos Patos. Influência nos depósitos lamíticos costeiros. Pesquisas 1993, 20, 57-69. [CrossRef]

44. Vaz, A.C.; Möller, O.O., Jr.; de Almeida, T.L. Análise quantitativa da descarga dos rios afluentes da Lagoa dos Patos. Atlântica 2006, 28, 13-23.

45. Bitencourt, L.P.; Fernandes, E.H.; da Silva, P.D.; Möller, O. Spatio-temporal variability of suspended sediment concentrations in a shallow and turbid lagoon. J. Mar. Syst. 2020, 212. [CrossRef]

46. Möller, O.O.; Castaing, P.; Salomon, J.C.; Lazure, P. The Influence of Local and Non-Local Forcing Effects on the Subtidal Circulation of Patos Lagoon. Estuaries 2001, 24, 297. [CrossRef]

47. Paim, P.S.G.; Möller, O.O. Material em Suspensão e Dissolvido no Estuário da Lagoa dos Patos—Fase III; Technical Report; FURG/CIRM: Rio Grande, Brazil, 1986.

48. Antiqueira, J.; Calliari, L.; Fontoura, J. Geomorphologic evolution of a sand spit located in the mouth of a choked coastal lagoon. Lagoa dos Patos: Southern Brazil. J. Coast. Res. 2004, 2004, 2004-2007.

49. Miranda, L.B.; M C, B.; Kjerfve, B. Princípios de Oceanografia Física de Estuários; Edusp: São Paulo, Brazil, 2002.

50. Jung, B.M.; Fernandes, E.H.L.; Möller, O.O.; García-Rodríguez, F. Estimating suspended sediment concentrations from river discharge data for reconstructing gaps of information of long-term variability studies. Water 2020, 12, 2382. [CrossRef] 